\title{
Dimethyl Sulfide In Cigarette Smoke - On the Origin of the Sulfur Compounds of Cigarette Smoke and on Their Possible Contributlon to its Overall Flavor and Aroma*
}

by Roger J. Philippe

Liggett and Myers Tobacco Co., Research Department,

Durham, N.C., USA

INTRODUCTION

Gas-solid chromatography on partially deactivated alumina was found to be a convenient technique to isolate the low molecular weight hydrocarbons from cigarette smoke $(1,2)$. Although somewhat time-consuming for the $C_{5}$ and $C_{0}$ hydrocarbons, this method gave fair resolution, reproducible retention times and, combined with a preliminary "ascarite" treatment, fractions almost free from polar compounds. Followed by further fractionation by gas-liquid chromatography, this technique led to the isolation and identification of some 50 hydrocarbons from 30 peaks eluted over a period of $10^{1 / 2}$ hours (Fig. 1 and 2). Only three non-hydrocarbon compounds were found in the eluate: nitrous oxide, methyl chloride and furan; a fourth such compound has now been identified, namely, dimethyl sulfide.

FIGURE I

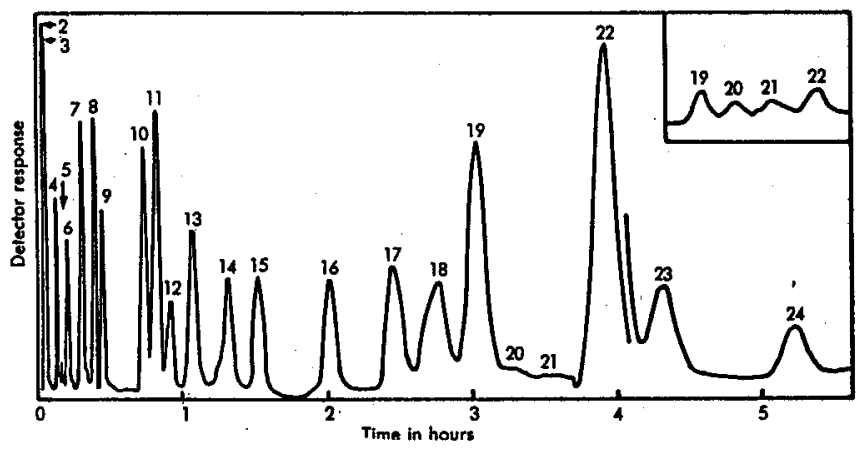

Gas chromatograms on alumina of the liquid air condensable fraction of the gas phase of eigarette smoke

FIGURE 2

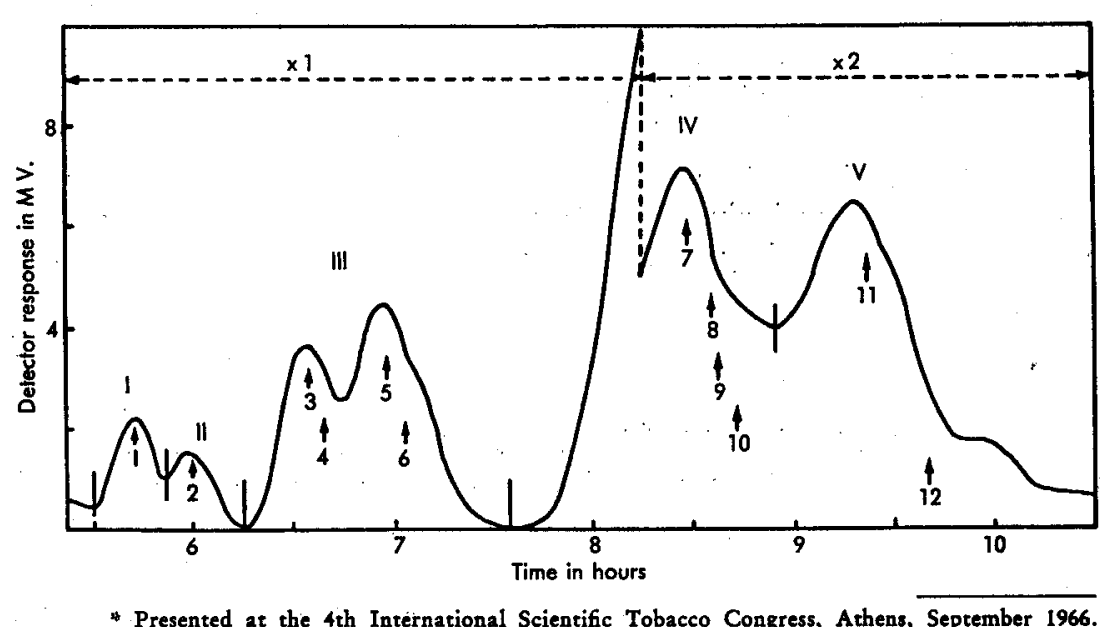

* Presented at the 4th International Scientific Tobacco Congress, Athens, September 1966. 
EXPERIMENTAL

1.1 Cigarettes

1. Cigarettes and Smoking Parameters

Tobacco: American commercial blend,

Length and diameter in mm.: 85 and 8.0,

Weight in $8 .: 1.20$ to 1.24 ,

Conditioning: $74^{\circ} \mathrm{F}$ and $60 \%$ R.H.,

Number: Total of 535 cigarettes smoked in 20 groups of 23 to 33 units.

\subsection{Smoking Parameters}

Nominal puff volume in $\mathrm{ml}: 40$,

Puff duration in sec: 2 ,

Puff frequency: one per minute,

Puff number per cigarette: 8 ,

Average butt length in $\mathrm{mm}: 44$.

2.1 Apparatus (Fig. 3)

2. Smoking Apparatus and Procedure

1. Cambridge Filter with latex rubber sleeve,

2. Critical flow orifice,

3. Three-way stopcock leading either to a $40 \mathrm{ml}$ bulb or to a series of gas traps,

4. A stopcock - equipped U-trap,

5. A conventional gas-handling vacuum apparatus (not shown).

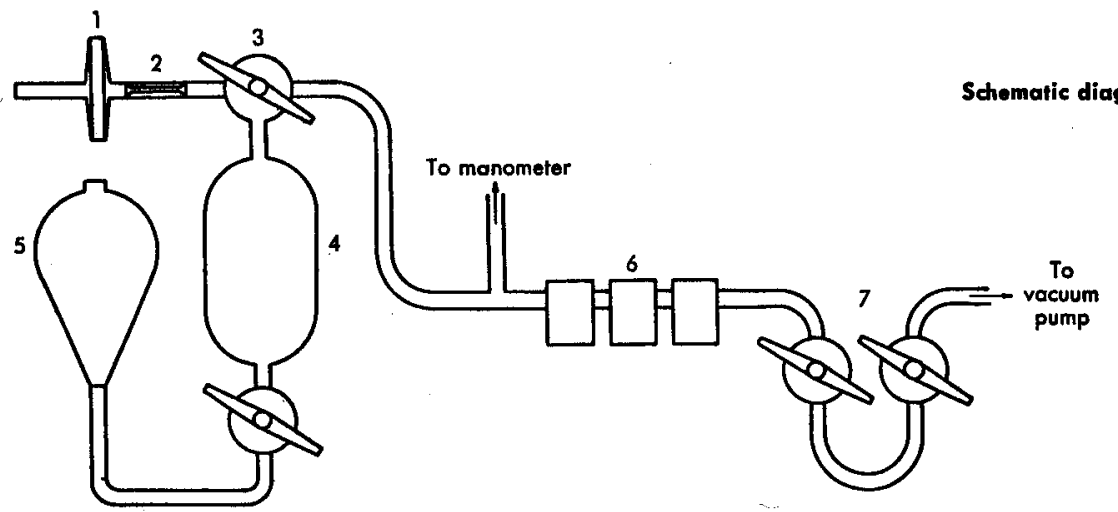

FIGURE 3

2.2 Procedure

- Cigarettes smoked manually, one at a time.

- Gas-vapor phase of each puff quantitatively collected in liquid air-cooled traps.

- Gas-vapor phase of a group of cigarettes transferred to vacuum apparatus for ascarite treatment.

- Chromatography on alumina, recovery of the eluate and storage at liquid air temperature.

- Pooled eluates from 535 cigarettes chromatographed on alumina and fractions studied by I. R. spectrophotometry and mass spectrometry.

3. Analytical Instruments

3.1 Infrared Spectrophotometer

Perkin-Elmer Model No. $2 \pi$ with $\mathrm{NaCl}$ prism and ordinate scale expander.

Modified Barnes Eng. M. G. microgas cell of $50 \mathrm{~mm}$ pathlength.

3.2 Mass Spectrometer

Bendix Time-of-Flight Model 14-101 with Sanborn recorder Model 152-100B. 


\subsection{Gas Chromatographs}

(two instruments labelled I and II).

\begin{tabular}{|c|c|c|}
\hline & \\
\hline & 1 & II \\
\hline Model & Laboratory built & Modified P.E. No. 154 \\
\hline Column & $\begin{array}{l}1 / 4^{\prime \prime} \text { diam., 9-foot } \\
\text { coiled copper tubing }\end{array}$ & Same as I but 15-foot \\
\hline Column material & $\begin{array}{l}\text { Burrell alumina, activated, } \\
\text { cat. no. } 341-35\end{array}$ & $\begin{array}{l}\text { Same as I but with } \\
18.7 \%(W t / w t) 3,3 \\
\text { oxydipropionitrile (O.D.P.N.) }\end{array}$ \\
\hline Column temperature & Room- (in Dewar Flask) & $30^{\circ} \mathrm{C}$ \\
\hline Detector & Thermal conductivity (Thermistors) & Same as I \\
\hline Detector temperature & About $35^{\circ} \mathrm{C}$, controlled to $\pm 0.1^{\circ} \mathrm{C}$ & $30^{\circ} \mathrm{C}$ \\
\hline Carrier gas & $\begin{array}{l}\text { He over } \mathrm{CuSO}_{4} \cdot 5 \mathrm{H}_{2} \mathrm{O}- \\
\mathrm{CuSO}_{4} \cdot 3 \mathrm{H}_{2} \mathrm{O} \text { at } 50 \mathrm{ml} / \mathrm{min} \text {. }\end{array}$ & He at $40 \mathrm{ml} / \mathrm{min}$. \\
\hline Injection system & $\begin{array}{l}\text { Solenoid operated from a } \\
\text { calibrated capillary gas trap }\end{array}$ & Same as 1 \\
\hline Recovery system & $\begin{array}{l}\text { Solenoid operated, in coiled } \\
\text { traps immersed in liquid air }\end{array}$ & Same as I \\
\hline
\end{tabular}

\section{RESULTS AND DISCUSSION}

The unusual shape of several absorption bands in the infrared spectrum of fraction $\mathrm{V}$ of Fig. 2 suggested the presence of a non-hydrocarbon in this fraction. Its mass spectrum confirmed this presumption, several mass peaks not being explained by the fragmentation pattern of 2-methylpentene-2 or of any other hexene. This fraction was separated in four sub-fractions on alumina + O.D.P.N. The three first sub-fractions were composed respectively of 2-methylpentene-2 and of two unidentified hexenes as reported earlier (2). The last sub-fraction was collected from 43 to $57 \mathrm{~min}$., the peak retention time being $50 \mathrm{~min}$.

The strong and typical smell at the column exit suggested the presence of a sulfur compound. The infrared spectrum of this fraction had all the characteristic absorption bands of known dimethyl sulfide as shown in Fig. 4. These bands are:

1. In the $-\mathrm{CH}$ stretching region, the 2985,2924 and $2882 \mathrm{~cm}^{-1}-\mathrm{CH}_{3}$ bands, appearing at slightly higher frequencies than in hydrocarbons due to the proximity of the sulfur atom.

2. The 1465 and 1445 bands of the asymmetric $-\mathrm{CH}_{3}$ bending vibration, relatively little affected by the neighboring sulfur.

3. The symmetric $-\mathrm{CH}_{3}$ bending vibration band with its characteristic P.Q.R. structure, the $Q$ branch of which being shifted downward to $1320 \mathrm{~cm}^{-1}$ by the adjacent $S$ atom.

4. Three additional bands, probably the $-\mathrm{CH}_{8}$ rodking vibrations, appearing at 1040, 1023 and $975 \mathrm{~cm}^{-1}$.

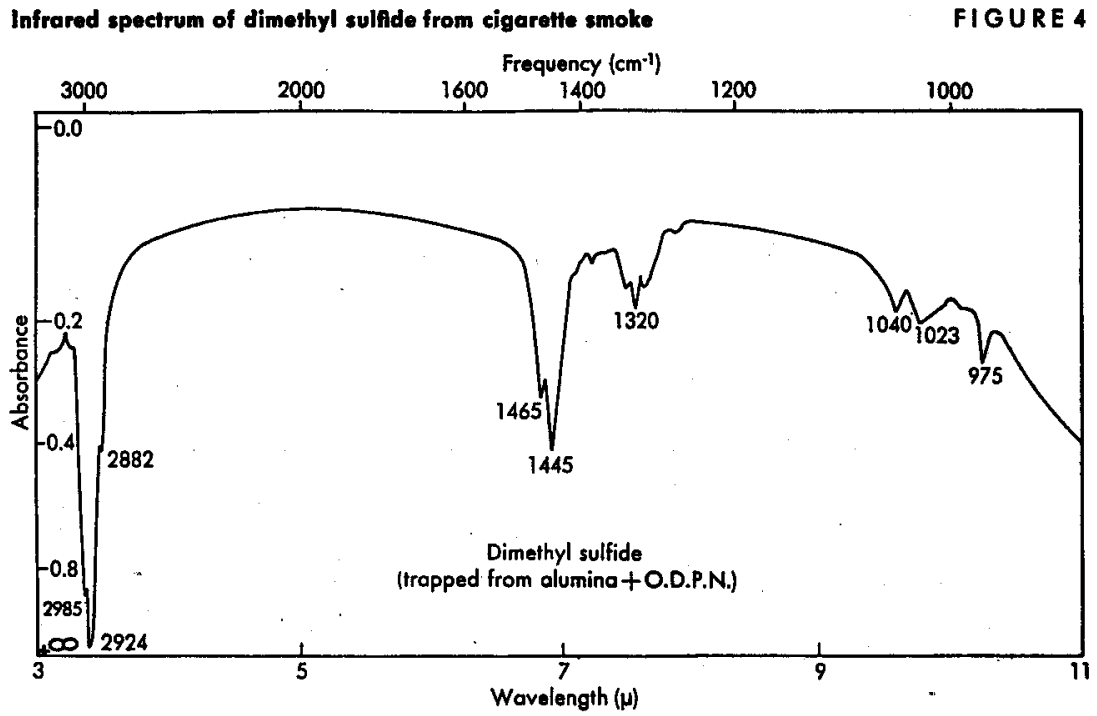


Mass spectra of dimothyl sulfde: authentic and isolated from cigarette smoke

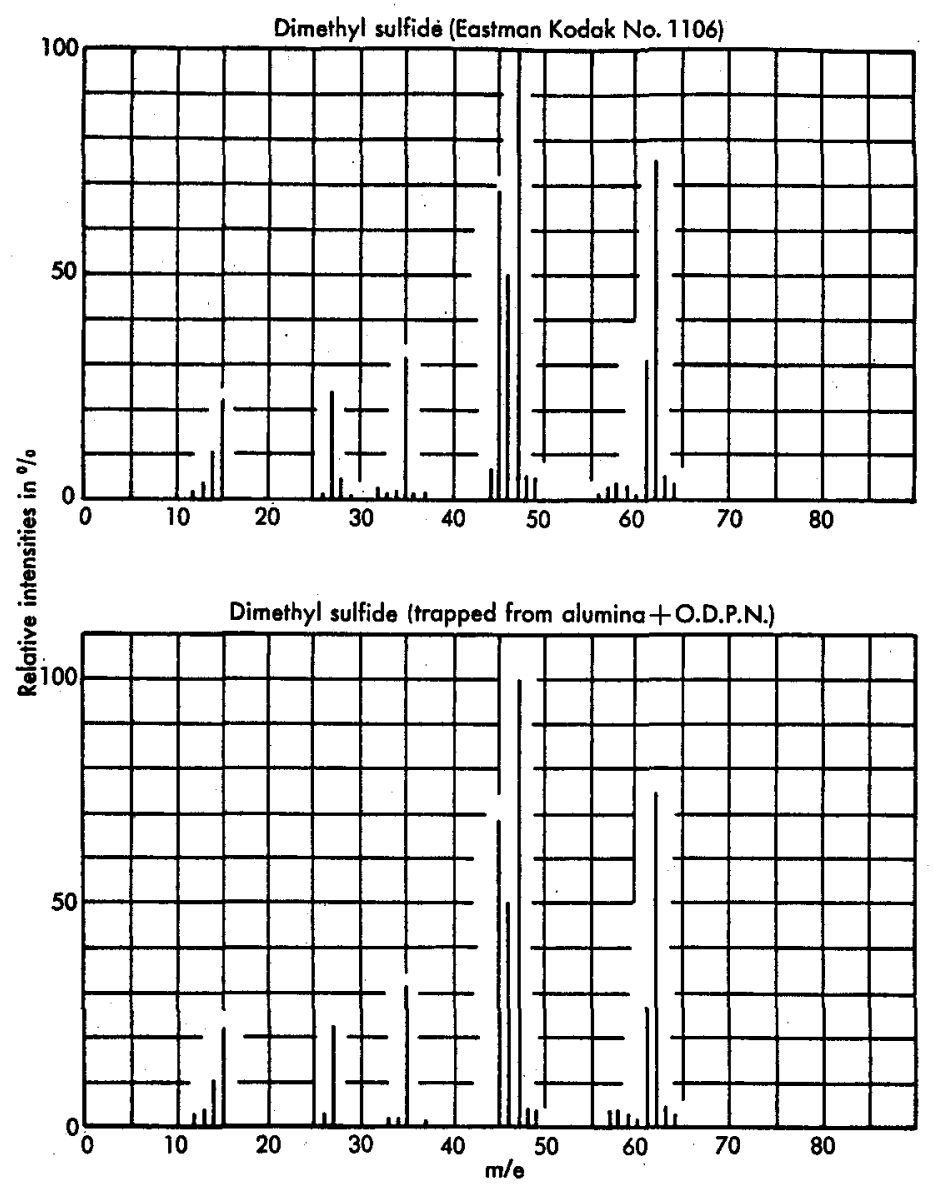

The mass spectrum of this fraction agreed also very well with the one of authentic dimethyl sulfide as shown in Fig. 5. The relative ease with which sulfur compounds acquire a positive charge under electron impact or cleave with retention of that charge on the sulfur containing fragment is well illustrated. The high relative intensity molecular-ion peak $(75 \%)$ appears at $\mathrm{m} / \mathrm{e} 62$; a sizable $\mathrm{m} / \mathrm{e} 6 \mathrm{I}$ peak corresponds to the $(M-1)+$ ion. The base peak occurs at $\mathrm{m} / \mathrm{e}$ 47 corresponding to the fragmentation $(M-15)^{+}$. Other major peaks having relative intensities higher than $20 \%$ appear at $\mathrm{m} / \mathrm{e} 46$, $45,35,27$ and 15 due most probably to the ion-fragments $\left(\mathrm{CH}_{2} \mathrm{~S}\right)^{+}, \quad(\mathrm{CHS})^{+}, \quad\left(\mathrm{H}_{3} \mathrm{~S}\right)^{+}$, $\left(\mathrm{C}_{2} \mathrm{H}_{3}\right)^{+}$and $\left(\mathrm{CH}_{3}\right)^{+}$respectively. Two pairs of satellites are also highly characteristic of dimethyl sulfide, namely, those appearing at $\mathrm{m} / \mathrm{e} 63$ and 64 , and at $\mathrm{m} / \mathrm{e} 48$ and 49. The peaks at $\mathrm{m} / \mathrm{e} 49$ and 64 are accounted for by the isotopic molecules containing $\mathrm{S}^{34}$ which has a natural abundance of 4 to $4.5 \%$. The $\mathrm{m} / \mathrm{e} 48$ and 63 peaks are explained by the cumulative contri-

butions of ions normally corresponding to masses 47 and 62 respectively but containing the isotopes $\mathrm{C}^{13}, \mathrm{H}^{2}$ or $\mathrm{S}^{33}$ and of ions of normal masses 46 and 61 but with isotope $\mathrm{S}^{34}$. Confirmation of the identity of dimethyl sulfide was also obtained by the retention times of an authentic sample on both columns used in this investigation; these retention times were $9 \mathrm{~h} 40 \mathrm{~min}$. on alumina and $50 \mathrm{~min}$. on alumina + O.D.P.N.

A semi-quantitative estimation of the amount of dimethyl sulfide in cigarette smoke, based on gas chromatographic measurements and taking into account the various collection, transfer and recovery losses, gave between 0.1 and $0.2 \mu \mathrm{g} / \mathrm{puff}$.

Relatively few sulfur compounds have been so far identified in cigarette smoke, practically all of them in the gas-vapor phase; they include thiocyanogen (3), thiocyanic acid (4), hydrogen sulfide $(5,6,7,8)$; carbonyl sulfide $(9,10)$, carbon disulfide (II), methyl thionitrite (II), thiophene $(12,6)$ and dimethyl sulfide. Two other probable sulfur containing constituents are methyl mercaptan and dimethyl disulfide, respectively a possible precursor and a decomposition product of methyl thionitrite, as well as an oxidation product of methyl mercaptan. Very little can be said concerning the origin of these sulfur compounds present in tobacco smoke since very little is known about the sulfur containing compounds of tobacco itself. According to Wenusch (24), sulfur is absorbed by the plant as the sulfate ion and occurs in the plant body as sulfates, esters of sulfuric acid and sulfur containing proteins, and plays an important part in the physiology of the plant through the redox system $\mathrm{S}-\mathrm{S}+2 \mathrm{H} \rightleftharpoons 2 \mathrm{SH}$. On a moisture-free basis, the weight percentage of sulfur of the main types of tobaccos used in the manufacture of a typical American blended cigarette varies from 0.4 for Virginia flue-cured tobacco to 1.1 for Maryland tobacco (13). Hydrogen sulfide present in tobacco smoke seems to be formed from tobacco proteic substances (8). Carbonyl sulfide has been found in the $250^{\circ} \mathrm{C}$ tobacco pyrolysis products 
(14) as well as in cigarette smoke $(9,10)$. A low-energy process would therefore be sufficient for its formation such as, for instance, the hydrolysis of isothiocyanic esters commonly found as glycosides in many plants. On the other hand, carbon disulfide was found only in cigarette smoke (II), which suggests a high temperature of formation, for example between elemental sulfur vapor and carbon.

Sulfur compounds are usually associated with a bad, even repulsive smell. However, in the proper concentration, they contribute to the characteristic flavor of several natural products, such as garlic and onion (15), horseradish, turnip, water cress, rutabaga, etc. (16) for which the identified active flavor compounds are several mercaptans, sulfides, disulfides, trisulfides and isothiocyanates. Sulfur compounds have also been detected in cooked meat vapors (17), in roasted coffee volatiles (18) and in milk where dimethyl sulfide in particular is an important flavor ingredient (19) found to have a desirable effect, at the appropriate level, according to organoleptic tests (20). Some synthetic flavor compositions include sulfur compounds, either in relatively high concentration (10\%) such as $\alpha$-furfuryl mercaptan for coffee (21), or merely as a trace (100 ppm) such as diallyl sulfide in raspberry flavor (22). According to Hewitt et al. (23) and I quote ". . . relatively simple sulfur containing compounds will be found to occur widely in the volatiles from food stuffs, probably at sub-threshold concentrations where they may have important modifying effects on the principal flavor constituents". It is probable, considering the very low flavor threshold of many sulfur compounds [some $12 \mathrm{ppb}$. for $\left(\mathrm{CH}_{3}\right)_{2} \mathrm{~S}$ for example (19)] and the relatively high level at which some sulfur compounds occur in the smoke of a blended cigarette as shown in Table 1 that they have a definite, characteristic effect on the aroma of that smoke.

Whether all these sulfur compounds or some of them impart beneficial or undesirable notes to the overall smoke aroma could be a challenging future study, especially since the use of adsorption-type filters which may modify both the absolute and relative concentrations of these compounds.

TABLE 1

SUMMARY

Sulfur containing compounds identified in cigarefte smoke

\begin{tabular}{l|c}
\hline Compound & $\begin{array}{c}\text { Approximate concentration in } \\
\text { total gas phase in p.p.m. (V/V) }\end{array}$ \\
\hline $\mathrm{H}_{2} \mathrm{~S}$ & 55 \\
$\mathrm{COS}$ & 50 to 60 \\
$\mathrm{CH}_{3} \mathrm{SNO}$ & 10 to 20 \\
$\left(\mathrm{CH}_{3}\right)_{2} \mathrm{~S}$ & 1 to 2 \\
$\mathrm{CS}_{2}$ & 0.8 \\
Thiophene & 0.6 to 1.0 \\
\hline
\end{tabular}

Dimethyl sulfide has been isolated from cigarette smoke by a combination of adsorption and partition gas chromatographic techniques. Positive identification of dimethyl sulfide was obtained by infrared spectrophotometry, mass spectrometry and gas chromatographic retention times. Both infrared and mass spectra are presented and their most important features are discussed. Based on gas dromatographic measurements, a semiquantitative estimation of the amount of dimethyl sulfide in cigarette smoke is given.

A list of the sulfur compounds identified up to now in cigarette smoke is presented as well as some discussion about their possible origin. After some evidence given on the importance of sulfur compounds on the flavor of several natural products and of some synthetic compositions, the question is raised as to the possible effect of these sulfur compounds on the overall flavor and aroma of cigarette smoke.

\section{ZUSAMMENFASSUNG}

Aus Cigarettenrauch wurde durch Gaschromatographie bei kombinierter Anwendung von Adsorptions- und Verteilungsverfahren Dimethylsulfid isoliert. Die Verbindung wurde mit Hilfe ihrer Infrarot- und Massenspektren sowie ihrer gaschromatographischen Retentionszeiten identifiziert. Die Spektren werden dargestellt und ihre wesentlichen Merkmale diskutiert. Auf der Grundlage der gaschromatographischen Befunde wird eine semi-quantitative Abschätzung der im Cigarettenrauch vorhandenen Menge an Dimethylsulfid mitgeteilt.

Die bisher im Cigarettenrauch nachgewiesenen Sdhwefelverbindungen werden zusammengestellt und ihre mögliche Herkunft wird besprochen. Nach dem Hinweis auf die große Bedeutung, die 
Schwefelverbindungen fiir den Geschmack mehrerer Naturprodukte und einiger synthetischer Verbindungen haben, wird die Frage erhoben, welchen Einfluß die Schwefelverbindungen möglicherweise auf den Geschmadk und das Aroma des Cigarettenrauches ausüben.

RESUME

Le sulfure de diméthyle a été isolé de la fumée de cigarette par chromatographie en phase gazeuse en utilisant une combinaison des techniques d'adsorption et de partage. Ce composé a été identifié à l'aide de ses temps de rétention, et de ses spectres infrarouge et de masse, spectres qui sont présentés et dont les caractéristiques principales sont discutées. On donne également une valeur approximative, obtenue par chromatographie en phase gazeuse, de la quantité de sulfure de diméthyle contenue dans la fumée de cigarette.

Les composés sulfurés identifiés jusqu'à présent dans la fumée de tabac sont relevés ainsi que quelques données sur leur origine probable. Après une digression sur le rôle important joué par plusieurs composés sulfurés dans la saveur et l'arôme de certains produits comestibles, tant naturels que synthétiques, un problème est posé concernant l'effet que peuvent avoir les composés sulfurés sur le gout et l'arôme de la fumée de cigarette.

REFERENCES

1. Philippe, R. J., Moore, H., Honeycutt, R. G., and Ruth, J. M.: Anal. Chem. 36 (1964) 859.

2. Philippe, R. J., Honeycutt, R. G., and Ruth, J. M.: J. of Chromatography 20 (1965) 250.

3. Toth, J.: Chem. Ztg. 33 (1909) 1301; Chem. Abstracts 4 (1910) 1068.

4. Schöller, R.: Fachliche Mitt. Osterr. Tabakregie 1938, I-4.

5. Fishel, J. B., and Haskins, J. F.: Ind. Eng. Chem. 41 (1949) 1374.

6. Newsome, J. R., Norman, V., and Keith, C. H.: Tobacco Science 9 (1965) 102.

7. Toth, J.: Chem. Ztg. 37 (1913) 897; Chem. Abstracts 8 (1913) 1850.

8. Wenusch, A.: Z. Untersuch. Lebensm. 70 (1935) 201.

9. Osborne, J. S., Adamek, S., and Hobbs, M. E.: Anal. Chem. 28 (1956) 211.

10. Philippe, R. J., and Hobbs, M. E.: Anal. Chem. 28 (1956) 2002.

11. Philippe, R. J., and Moore, H.: Tobacco Science 5 (1961) 121.

12. Grob, K.: Proceedings of the Third World Tobacco Scientific Congress, Salisbury, 1963, p. 564 .

13. Harlan, W. R., and Moseley, J. M.: Tobacco, Encyclopedia of Chemical Technology, McGrawHill, New York, 1955, p. 242.

14. Philippe, R. J.: Unpublished results, Research Department, Liggett and Myers Tobacco Co., Durham, N.C., 1958.

15. Oaks, D. H., Hartman, H., and Dimick, K. P.: Anal. Chem. 36 (1964) 1560.

16. Meyer, L. H.: Volatile Sulfur Compounds, Food Chemistry, Reinhold, New York, 1960, p. 278.

17. Meyer, L. H. : Meat and Meat Products, Meat Aroma, ibid., p. 205.

18. Meyer, L. H.: The Flavor and Aroma of Food, Recent Developments in Flavoring Research, ibid., p. 167.

19. Patton, S.: Chemical Aspects of Flavor Research on Milk and Its Products, Flavor Research and Food Acceptance, Reinhold, New York, 1958, p. 315.

20. Patton, S., Forss, D. A., and Day, E. A.: J. Dairy Sci. 39 (1956) 1469.

21. Meyer, L. H.: Recent Developments in Flavoring Research, Food Chemistry, Reinhold, New York, 1960, p. 165.

22. Meyer, L. H.: ibid., p. 164.

23. Hewitt, E. J., Mackay, D. A. M., and Lewin, S. Z.: Physicochemical Approaches to the Study of Flavor, Flavor Research and Food Acceptance, Reinhold, New York, 1958, p. 286.

24. Wenusch, A.: Chemie des Tabakblattes, Arthur Geist Verlag, Bremen, 1940, p. 44.

Acknowledgement

I thank Drs. J. D. Mold, J. M. Ruth and Mr. R. G. Honeycutt, all of Liggett and Myers Tobacco Company's Research Department, for their assistance in preparing this manuscript.

The author's present address:

Tabacofina, S. A., Research Department, 123 Bredabaan, Merxem-Antwerp, Belgium. 